\title{
IAMJ
}

INTERNATIONAL

AYURVEDIC

MEDICAL JOURNAL

\section{CRITICAL REVIEW ON PANCHAMRITHA - THE MAGICAL COMBINATION WHICH MODIFIES LIFE}

\author{
Sneha M S ${ }^{1}$, Rekha. $\mathbf{R}^{2}$ \\ ${ }^{1} \mathrm{PhD}$ Scholar, Department of Dravyaguna Vijnana, Parul Institute of Ayurveda, Vadodara, Gujrat, India \\ ${ }^{2}$ Junior Research Fellow, Astangam Ayurveda Chikitsalayam \& Vidyapeedham, Vavanoor, Kootanad, Palakkad, \\ Kerala, India
}

Corresponding Author: snehagiriprasad@gmail.com

https://doi.org/10.46607/iamj11 p6012021

(Published online: November 2021)

Open Access

(C) International Ayurvedic Medical Journal, India 2021

Article Received: 07/09/2021 - Peer Reviewed: 19/11/2021 - Accepted for Publication: 23/11/2021

Check for updates

\begin{abstract}
Panchamritha is a combination of five ingredients which are Goksheera (cow's milk), Dadhi from Goksheera (curd from cow's milk), Goghrita (cow's ghee), Kshoudra (honey) and Sarkara (sugar). Panchamritha improves immunity and physical strength. Panchamritha is considered as Rasayana because all the five ingredients will support each other to reach the target area of the body, proper absorption and assimilation. It helps to support brain functions like intelligence, memory, grasping power and creative abilities. Panchamritha is a rare combination of Vedas which have both religious and health benefits. It is a combination of five nutraceutical products as ingredients that will support each other to reach the target area of the body, proper absorption and assimilation. This traditional combination is having almost all the proteins, vitamins, micro and macro elements and it helps in the development and functioning of the body. This article highlights and correlates the scientific evidence for the nutraceutical value of Panchamritha.
\end{abstract}

Keywords: Panchamritha, Ksheera, Gogritha, Dadhi, Madhu, Sarkara 


\section{INTRODUCTION}

Ayurveda is a healthcare system of medicine that prioritise Svasthyarakshana (maintenance of the healthy state of body and mind) than Aaturavikaara Prasamana (treating a disease). The concept of Vayasthapana (anti-ageing) is described in Ayurveda as 'Rasaayana', which aims at maintaining excellent physical and mental health in adult age. The word 'Rasaaya$n a$ ' means clearing the Srotas for the natural flow of matter and energy. Rasaayana aims to improve the body's mechanism of repair and detoxification thereby maintaining better immunity, circulation, musculoskeletal strength and other psychophysiological wellness (Prasannaatmendriya and mana)

Five substances like godughdha, dadhi, gritha, madhu and sarkara are in the specific ratio is called panchamritha. According to Hindu mythology, the gods gained immortality by drinking Panchamrita. Panchamruta - derived from 'Pancha' + 'Amru$t a$ 'Each of the ingredients has symbolic significance. Milk - piousness and purity, Curd - prosperity and progeny, Honey - unity and sweet speech, Sugar bliss, Ghee - victory and knowledge ${ }^{[1]}$. All religious Hindu rituals are incomplete without the Panchamrita (Panchamrita Prasada). It is used as an offering during poojas (bhoga prasada). It is used as a libation during Abhisheka (panchamrith aabhisheka).

\section{MATERIALS AND METHODS}

Compilation and tabulation were done from classical text, nighantus, internet publications and journals

GODUGDHA (Cow's milk)

Godugdha is having Madhura Rasa (sweet taste) and Vipaka, Sita Virya, (cold potency) Snigdha(unctuousness) and Guru Guna (heaviness quality). It alleviates Vata-Pittaand Raktha.Bhavaprakasha says that the regular intake of Dugdha prevents all diseases and ageing [2]. Yogaratnakara states that dugdha possess rasayana, Brhmana (nourishing), Balya (strengthening) and Jeevana properties. Godugdha is also indicated in JeernaJwara, (chronic fever) Mutrakrichra (Dysu-
ria)Madatyaya, (Alcoholism) Raktapitta (Bleeding disorder) Kasa(cough) and Swasa(breathlessness) ${ }^{[3]}$. It increases Ojas (vitality) from having similar properties. It acts as Rasayana (immunomodulator and rejuvenator) ${ }^{[4 .]}$

Cow milk contains carbohydrates, protein, fat, vitamins and minerals. Vitamins like vitamin A, C, D E, B6, B9 thiamine, riboflavin, niacin, and pantothenic acid. Minerals like calcium, iron, magnesium, phosphorus, potassium, sodium, zinc etc. It also contains essential amino acids such as tryptophan, threonine, isoleucine, leucine, lysine, methionine and cysteine ${ }^{[5]}$ and it contains immunoglobulins, hormones, growth factors, cytokines, nucleotides, peptides, polyamines, enzymes and other bioactive peptides. The lipids like oleic acid, conjugated linoleic acid, omega-3 fatty acids, short- and medium-chain fatty acids, vitamins, minerals and bioactive compounds help to promote health ${ }^{[.6]}$

Many studies reported that milk Proteins have effects on digestive function, anti-carcinogenic activity and act as an immune modulator. Milk proteins have numerous Amino acids which are alkaline. It supports the stomach during digestion and has the power to regulate the circulatory and central nervous systems. It also cleanses the auto-synchronous human body. Lactoferrin- helps in the regulation of iron homeostasis, develops immunity for microbial infections due to its anti-inflammatory action. Hydrolysis of Lactalbumin generates peptides that activate phagocytosis via specific receptors, thus maintaining the immunity in the body ${ }^{[7 .]}$

Cow milk is a healthy nutriment because of low calories, less cholesterol and high micro-nutrients. It possesses rejuvenating and protecting properties due to this combination acting as the best vitalizers. It has a protective effect in pregnancy and is easily digestible ${ }^{[8,9]}$ It helps to cure fever, pain, diabetes and weakness [10]. 
Table 1

\begin{tabular}{|c|c|c|c|}
\hline $\begin{array}{l}\text { Milk compo- } \\
\text { nent }\end{array}$ & $\begin{array}{l}\text { Concentration in } 1 \text { l } \\
\text { whole milk }^{\mathrm{a}}\end{array}$ & $\begin{array}{l}\text { Percent contribution of } 0.5 \text { l } \\
\text { whole milk to reference intake }\end{array}$ & Health effects \\
\hline Fat & $33 \mathrm{~g} / \mathrm{l}$ & & Energy-rich \\
\hline $\begin{array}{l}\text { Saturated fatty } \\
\text { acids }\end{array}$ & $19 \mathrm{~g} / 1$ & & $\begin{array}{l}\text { Increase HDL, small dense LDL, and total } \\
\text { cholesterol. Inhibition of bacteria, virus }\end{array}$ \\
\hline Oleic acid & $8 \mathrm{~g} / \mathrm{l}$ & & Prevent CHD, gives stable membranes \\
\hline Lauric acid & $0,8 \mathrm{~g} / \mathrm{l}$ & & Antiviral and antibacterial \\
\hline Myrisitc acid & $3,0 \mathrm{~g} / \mathrm{l}$ & & Increase LDL and HDL \\
\hline Palmitic acid & $8 \mathrm{~g} / 1$ & & Increase LDL and HDL \\
\hline Linoleic acid & $1,2 \mathrm{~g} / \mathrm{l}$ & & Omega- 6 fatty acid \\
\hline $\begin{array}{l}\text { Alpha- } \\
\text { linolenic acid }\end{array}$ & $0,75 \mathrm{~g} / \mathrm{l}$ & & Omega- 6 fatty acid \\
\hline Protein & $32 \mathrm{~g} / \mathrm{l}$ & $30-40 \%$ & $\begin{array}{l}\text { Essential amino acids, bioactive proteins, } \\
\text { peptides. Enhanced bioavailability }\end{array}$ \\
\hline Lactose & $53 \mathrm{~g} / 1$ & & \\
\hline Calcium & $1,1 \mathrm{~g} / 1$ & $40-50 \%$ & Bones, teeth, blood pressure, weight control \\
\hline Magnesium & $100 \mathrm{mg} / \mathrm{l}$ & $12-16 \%$ & For the elderly, asthma treatment \\
\hline Zinc & $4 \mathrm{mg} / \mathrm{l}$ & $18-25 \%$ & Immune function. Gene expression \\
\hline Selenium & $37 \mathrm{ug} / 1$ & $30 \%$ & Cancer, allergy, CHD \\
\hline Vitamin E & $0,6 \mathrm{mg} / \mathrm{l}$ & $2 \%$ & Antioxidant \\
\hline Vitamin A & $280 \mathrm{ug} / 1$ & $15-20 \%$ & Vision, cell differentiation \\
\hline Folate & $50 \mathrm{ug} / \mathrm{l}$ & $6 \%$ & DNA synthesis, cell division, amino acid \\
\hline Riboflavin & $1,83 \mathrm{mg} / \mathrm{l}$ & $60-80 \%$ & $\begin{array}{l}\text { Metabolism } \\
\text { Prevent } \\
\text { Ariboflavinosis }\end{array}$ \\
\hline Vitamin $\mathrm{B}_{12}$ & $4,4 \mathrm{ug} / \mathrm{l}$ & $90 \%$ & Key role in folate metabolism \\
\hline
\end{tabular}

Milk composition and percent contribution to the daily dietary reference intakes of some nutrients in 0.51 whole milk, and their main health effects. ${ }^{[11]}$

\section{DADHI (Cow's curd)}

Cow curd is Madhura-Amla Rasa with Kashaya anurasa, Snigdha and Guruguna, Ushna Virya (Hot potency), Amla Vipaka, Balavardhaka, Vatanashaka, (alleviate vata) and Ruchikaraka. It is Agnideepaka (digestive) Shukravardhaka, Snehana, Grahi (Constipated), Balavardhaka, Medovardhaka (excess fat tissue) mamsavardhana (excess muscle tissue), Mangalakari (Auspicious) and used in Aruchi (Anorexia) Mutrakruchha, Pratisyaya (Rhinitis), Sheetakajwara, Vishamajwara, Kasa, \&Karshya (Lean). ${ }^{[12,13]}$

Table 2: Nutritional value of Curd ${ }^{[14]}$

\begin{tabular}{|l|l|}
\hline Content of curd & Nutritional value \\
\hline Total Fat & $3.1 \mathrm{~g}$ \\
\hline Saturated fat & $1.9 \mathrm{~g}$ \\
\hline Cholesterol & $8 \mathrm{mg}$ \\
\hline Total Carbohydrate & $4.4 \mathrm{~g}$ \\
\hline Protein & $4.1 \mathrm{~g}$ \\
\hline Calcium & $83 \mathrm{mg}$ \\
\hline
\end{tabular}

Dadhi rich in vitamins like B-12, riboflavin, protein, minerals like calcium, magnesium, phosphorous, iodine, Zinc, and Lactic acid bacteria. Lactic acid bacteria act as a potential source of probiotics. Curd's unique fermented food matrix provides added health benefits by enhancing nutrient absorption. The fermented product, increase the bioavailability of vitamin B-12, calcium, magnesium, protein and peptides. It is suitable for children and elder people which helps in skeletal muscle mass. ${ }^{[15] .}$ 
Bacteria act as a source of probiotics, which helps maintain the microbial equilibrium in the gastrointestinal tract. The curd increases the absorption of nutrients and reduces gastrointestinal perturbation ${ }^{[15]}$

\section{GOGHRITA (Cow's Ghee)}

Goghritha is included in Madhura Skandha by Astanga Hridaya [16]. The Properties of Ghritha is Madhura Rasa and Vipaka, Sita Virya and Guru, Snigdha Guna. It is having the Prabhava as Agnideepana. It is Rasayana, Chakshusya (Improve vision), Tridoshashamaka (Alleviate tridosha) Vishanashaka (Anti poisonous), Alakshmeehara (Auspicious), Papanashaka, Alpabhisyandi, Kanthivardhaka (good for skin), Ojovardhaka, Lavanyakaraka, Smritikaram (Increase memory), Medakaram, Ayushyam, (Longevity) Balakaram, Rakshoghna (Protection) Vayasthapana, Mangalyakaraka, Rochan etc. Goghritha is considered the best among Ghrithas by legends of Ayurveda ${ }^{[17,18] \text {. }}$

It is useful in Kushtha, Vranashodhana (cleanses wound), Vranasandhana and Vranaropana (heals wound quickly). Acharya Vaghabhata describes the same as Acharya Shushruta [19]. Cow ghee is best amongst all Sneha. It has thousand good qualities and does a thousand actions when processed properly. ${ }^{[20] .}$ It is included as one of those ingredients that can be consumed daily ${ }^{[21]}$.

Ghee is fat processed by methods like the fermentation of cream, butter or milk and even heating processes. It is shelf-stable due to its low moisture content and the presence of natural antioxidants. Ghee is considered superior among other fat due to its shortchain fatty acids which are responsible for its better digestibility and anti-cancer properties.

Ghee is a carrier for fat-soluble vitamins (A, D, E, K) and essential fatty acids, apart from having rich and pleasant sensory properties. The flavouring contents of ghee are carbonyls, lactones and free fatty acids and it also possesses antioxidant activity

Medium-chain fatty acids (MCFAs) are absorbed directly by the liver and burned to provide energy. The energy formed from medium-chain fatty acids is responsible for burning other fats in the system and losing weight. Ghee exclusively contains butyric acid; a short-chain fatty acid, which contributes to its distinct flavour and easy digestion. Beneficial intestinal bacteria convert fibre into butyric acid and then use that for energy and intestinal wall support ${ }^{[22]}$

Table 3: Gross composition of Ghee ${ }^{[23] .}$

\section{Constituents}

Fat $(\%)$

Moisture (\%)

Carotene $(\mathrm{mg} / \mathrm{g})$

Vitamin A(IU/g)

Cholesterol (mg/100g)

Tocopherol(mg/g)

Free fatty acid (\%)
Cow milk ghee

$99-99.5$

$<0.5$

$3.2-7.4$

19-34

$302-362$

$26-48$

2.8

Table 4: Fatty acid composition of Ghee ${ }^{[24]}$

\begin{tabular}{|l|l|}
\hline Fatty Acid (\%) & Cow milk fat \\
\hline Butyric & 3.2 \\
\hline Caproic & 2.1 \\
\hline Capric & 2.6 \\
\hline Lauric & 2.8 \\
\hline Myristic & 11.9 \\
\hline Palmitic & 30.6 \\
\hline Stearic & 10.1 \\
\hline Oleic & 27.4 \\
\hline Linoleic & 1.5 \\
\hline Linolenic & 0.6 \\
\hline
\end{tabular}




\section{MADHU (HONEY)}

Madhu (Honey) Is A Semisolid Substance with Madhura Rasa and Kashaya anurasa, Ruksha (dryness), Vishada (clearness), Sukshma Guna (subtleness), Sita Virya and Madhur aVipaka. It Possess Chakshusya, Deepana, Grahi, Lekhan a(scraping), Vrana-shodhana-ropanam, Rochana, swiryam, Saukumaryam(tenderness), Srotovishodhana (Clear srotas), Hladana (pleasant), Vrishya (aphrodiasic) and Prasadana properties. The Indications for honey are Kushta (Skin disorder), Arsha (piles) Kasa (Cough) Rakthapitta, Kaphajavikara (Alleviate Kaphajavikara), Prameha (diabetis Mellitus), Klama (Fatigue), Krimiroga (worm infestations), Medoroga, Trishna, Chardiroga (Vomiting), Swasa, Hikka (Hiccough), Atisara (Anti diarrheoal), Vibandha (constipation) Dahahara (Reduce burning sensation), Kshatahara, and Kshayahara ${ }^{[25] .}$ As per Kaiyadeva Nighantu honey possess Medhya and vilepana properties. it aggravates Vata but a suitable time for conception of Madhu is Varsha Ritu (Rainy season) ${ }^{[26 .]}$ About 5500 years ago ancients' people have realised the importance of honey ${ }^{\text {[27.] }}$ They used honey for dai-

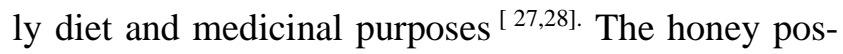

sesses antioxidant, antimicrobial, anti-inflammatory, antiproliferative, anticancer, and anti-metastatic properties. Flavonoids and polyphenols are the two antioxidants responsible for their antianti-ageing action. Honey intercept free radicals' molecules which are responsible for cell damage. Both enzymatic and non-enzymatic substances apply in protective antioxidant $^{\mathrm{s}}{ }^{[29]}$. Slow absorption leads to the production of short-chain fatty acid produced by slow absorption [30]. It is a likely mechanism that the ingestion of honey may result in SCFA production. The immunomodulatory actions of SCFA have been confirmed [31]. Therefore, honey may induce an immune response through these fermentable sugars ${ }^{[35]}$. A sugar, nigerooligosaccharides, present in honey has been observed to have immunopotentiating effects. ${ }^{[30]}$ Immunomodulatory activity of honey due to non-sugar content $\left[{ }^{30]}\right.$. Honey is of natural nutraceutical product which acts as an antioxidant ${ }^{[33] .}$ Honey has an action on the central nervous system which act as anxiolytic, antidepressant, anticonvulsant, and antinociceptive effects. Several studies on honey propose that honey polyphenols have nootropic and neuroprotective properties ${ }^{[34]}$.

Table 5: Carbohydrate and water percentage in Honey ${ }^{[36,37,38]}$

\begin{tabular}{|l|l|}
\hline Carbohydrate Components & Percentage \\
\hline Fructose & $38.2 \%$ \\
\hline Glucose & $31.3 \%$ \\
\hline Maltose & $7.1 \%$ \\
\hline Sucrose & $1.3 \%$ \\
\hline Water & $17.2 \%$ \\
\hline Higher sugars & $1.5 \%$ \\
\hline Ash & $0.2 \%$ \\
\hline Other/undetermined & $3.2 \%$ \\
\hline
\end{tabular}

\begin{tabular}{|c|c|}
\hline \multicolumn{2}{|c|}{ Nutritional value per $100 \mathrm{~g}(3.5 \mathrm{oz})$} \\
\hline Energy & $1,272 \mathrm{~kJ}(304 \mathrm{kcal})$ \\
\hline Carbohydrates & $82.4 \mathrm{~g}$ \\
\hline Sugars & $82.12 \mathrm{~g}$ \\
\hline Dietary fibre & $0.2 \mathrm{~g}$ \\
\hline Fat & $0 \mathrm{~g}$ \\
\hline Protein & $0.3 \mathrm{~g}$ \\
\hline Vitamins $^{[39]}$ & Quantity \\
\hline Riboflavin (B2) & $0.01-0.02 \mathrm{mg}$ \\
\hline
\end{tabular}




\begin{tabular}{|l|l|}
\hline Niacin (B3) & $0.1-0.2 \mathrm{mg}$ \\
\hline Pantothenic acid (B5) & $0.02-0.11 \mathrm{mg}$ \\
\hline Vitamin B6 & $0.024 \mathrm{mg}$ \\
\hline Folate (B9) & $2 \mu \mathrm{g}$ \\
\hline Vitamin C & $0.5 \mathrm{mg}$ \\
\hline Ascorbic acid & $2.2-2.5 \mathrm{mg}$ \\
Thiamine & $0-0.01 \mathrm{mg}$ \\
Minerals $\mathbf{3}^{9}$ & Quantity \\
\hline Calcium & $3-31 \mathrm{mg}$ \\
\hline Iron & $0.3-4.0 \mathrm{mg}$ \\
\hline Magnesium & $0.7-13.0 \mathrm{mg}$ \\
\hline Phosphorus & $2-15 \mathrm{mg}$ \\
\hline Potassium & $40-3500 \mathrm{mg}$ \\
\hline Sodium & $1.6-17 \mathrm{mg}$ \\
\hline Zinc & $0.05-2.0 \mathrm{mg}$ \\
\hline Copper & $0.02-0.60 \mathrm{mg}$ \\
\hline Manganese & $0.02-2.0 \mathrm{mg}$ \\
\hline
\end{tabular}

Honey has antioxidants, phenolic acids, flavonoids, ascorbic acid, organic acids, amino acids, and proteins ${ }^{[40] . ~ H o n e y ~ c h a r a c t e r i z a t i o n ~ h e l p s ~ u s ~ t o ~ u n d e r-~}$ stand its antioxidant characteristics, thereby, its use as a natural foodstuff, i.e., as a source of antioxidant human nutrition.

\section{SARKARA (JAGGERY SUGAR)}

Jaggery is non-centrifugal sugar (NCS) obtained by evaporation of water in sugarcane. Sugarcane crop is cultivated for the production of sugar, but the processing of sugarcane yields various valuable products such as brown sugar, molasses, syrup, and jaggery, along with sugar (table sugar) [41,42]. It is Shukravardhaka (aphrodisiac), used in treating Kshata-Ksheena (injured patients and emaciated people) [43]. Gudasharkara is more sheeta (coolant), sweeter, Vrushya, useful in Raktapitta (bleeding disorders) and Trishna (relieves thirst) ${ }^{[44] .}$

It consists of novel O-glycoside, dehydroconiferyl alcohol-9'-O- $\beta$-D-glucopyranoside along with the already reported isoorientin-7, 3'-Odimethyl ether was isolated as antibacterial compounds from sugarcane molasses. Scientific studies proved that it possesses anti-inflammatory, analgesic, antihyperglycemic, antihypercholesterolemic, antithrombotic, diuretic and hepatoprotective effects ${ }^{[45]}$.
The colour of jaggery varies from golden brown to dark brown and it constitutes of 50\% sucrose, $20 \%$ invert sugar, $20 \%$ moisture, and the remainder is insoluble matter such as ash, and protein. It contains minerals like calcium magnesium: potassium phosphorus, sodium iron manganese, zinc, copper, and chloride. Vitamins like vitamin A, B1, B2, B5, B6 C, E1: and protein. Gur is another form that is high calorie, and it contains minerals, protein, glucose, and fructose The high-quality Gur has $70 \%$ sucrose, less than $10 \%$ of fructose and glucose and $5 \%$ minerals. and it contains ferrous during its preparation in iron vessels. ${ }^{[46]}$.

\section{INGREDIENTS OF PANCHAMRITHA ${ }^{[47]}$}

Milk: 1cup

Thick curd or yoghurt: $1 / 2$ cup

Sugar; $1 / 4$ cup

Ghee: $1 / 4$ spoon

Honey: 3-4 drops

Panchamritha is the combination of the above 5 ingredients with a specified quantity. Panchamrutha is also called food for God (Amrut/Amrit) because it is having a lot of health benefits. It is given throughout the pregnancy for the good health of the mother and the proper development of the foetus. Panchamritha prepared with the right proportion is also considered a healthy recipe for brain function. Panchamrutha 
nourishes the skin and keeps it moist healthy. It works as good food for healthy hair. It also Boosts physical strength, improves potency (increases Shukra in the body) improves immunity, vitalizes the brain, enhances intelligence, memory, grasping power, creative abilities, improves complexion as it's considered as a skin cleanser. ${ }^{[47]}$

\section{DISCUSSION}

Panchamritha, a combination of five ingredients in different proportions is a divine mixture with numerous health benefits. The 5 ingredients are in unequal quantity especially the Ghrita and Madhu. Because Ghritha and Madhu in equal quantity are considered as Matravirudha by Ayurveda Acharyas. All the ingredients in the Panchamritha are Madhura rasa Pradhana, Madura Vipaka, Guru, Snigdha Gunayukta and Sheethaveerya Dravyas. The Rookshatwa and Sookshmatwa of honey will break all the obstructions in the Srotas and help to reach the nutrients into its target area. Dugdha is Ajanmasatmya and Ghritha is the first member of Madhura Skandhas. both are having Rasayana, Ojovridhikara, Shukravridhikara, Medhya properties. Dadhi is Agnideepaka, Ruchivardhaka, Balya etc and it will help for proper digestion and metabolism of food. Sarkara/Jaggery sugar should be considered as the Sarkara because it is the safest item from sugarcane and has many health benefits than the bleached white sugar (white poison). So, this combination is having many health benefits such as Medhya, Balya, Ojovridhikara, Agnideepana, Twachya etc.

\section{CONCLUSION}

Panchamritha is considered as Rasayana because all the five ingredients will support each other to reach the target area of the body, proper absorption and assimilation. This combination is having almost all the proteins, vitamins, micro and macro elements. Panchamritha is called Rasayana because this combination includes all the elements for the proper development and functioning of the body.

\section{REFERENCES}

1. Sen et.al, panchamritha -the five nectars of God, world journal of pharmaceutical and life sciences.,2018, vol 4 , issue 4,73-74

2. Prof.KrishnachandraChuneker, BhavaprakashaNighantu, dugdhavarga 6,7, ChoukambhaBharatiAcadamy, Varanasi, 2010 edition, p:742

3. Vaidya SreelakshmipathiShastry, Yogaratnakara, Vidyotini teeka,1/2,3, Chukambha Publication, Varanasi, p: 96.

4. Acharya Agnivesha, CharakaSamhita, Pt. KashiNathaShashtri, Dr GorakhaNathaShashtri, ChaukhambaBharati Academy, Part 1, Ch. Su.27/218, p: 550.

5. Nishant Kaushik et al, A critical analysis on the role of milk in lifestyle diseases, Ayushdhara, 2015, vol-2, issue-1, P: 25-34.

6. Ann Hauget.al, Arne T Hostmark et al, Bovine milk in human nutrition -a review, PMCID: PMC2039733, Published online 2007.

7. Nishant Kaushik et al, A critical analysis on the role of milk in lifestyle diseases, Ayushdhara, 2015, vol-2, issue-1, P: 25-34

8. Dhama K, Rathore R, Chauhan RS and Tomar S: Panchgavya- an overview. International Journal of Cow Science 2005; 1(1): 1-15.

9. Schnürer $\mathbf{J}$ and Magnusson $\mathrm{J}$ : Antifungal lactic acid bacteria as biopreservatives - review. Trends in Food Science and Technology 2005; 16(1-3): p: 70-78.

10. Sowrirajan M: PadharthaGunapadam (Tamil). Thanjavur Maharaja SarabojiyinSaraswatiMahalNoolagam, Thanjavur. 2006: p: 67

11. Ann Hauget.al, Arne T Hostmark et al, Bovine milk in human nutrition -a review, PMCID: PMC2039733, Published online 2007.

12. Acharya Priyavrit Sharma, Dr. Guruprasad Sharma, kaiadevaNighantu, ChukambhaOrientalia, Varanasi, Edition 2006 dadhivarga /186,187

13. Prof.KrishnachandraChuneker, BhavaprakashaNighantu, dadhivarga 186,187, ChoukambhaBharatiAcadamy, Varanasi, 2010 edition, p: 751

14. SayleeDeshmukhet. al. Review of Curd, Paneer and Cheese as NityaAsevaniyaAharaDravya, Journal of Ayurveda and Integrated Medical Sciences Jan - Feb 2017 Vol. 2 Issue 1

15. Melissa Anne Fernandez et.al, Potential Health Benefits of Combining Yogurt and Fruits Based on Their Probiotic and Prebiotic Properties, Published online 2017, Jan 11.

16. Anna MoreswaraKunte, Krishna RmachandraSastriNavare, Astangahridayam compiled by Vagbhata, ChukambhaOrientalia, Varanasi,2014 edition, AH.SU 10/22. p:176

17. Prof.KrishnachandraChuneker, BhavaprakashaNighantu, Ghritavarga 1-6, ChoukambhaBharatiAcadamy, Varanasi, 2010 edition, p:758. 
18. Acharya Priyavrit Sharma, Dr Guruprasad Sharma, kaiadevaNighantu, ChukambhaOrientalia, Varanasi, Edition 2006 ghritavarga /264-271, p: 367-368.

19. Acharya Sushruta, Sushruta Samhita, KavirajaAmbika Dutta Shashtri, "Ayurveda TattvaSandipika" Hindi Commentary, ChaukhambaSanskritaSamsthana, Varanasi, Reprint- 2012, Su. Su.45/132, p: 232.

20. Acharya Priyavrit Sharma, Dr Guruprasad Sharma, kaiadevaNighantu, ChukambhaOrientalia, Varanasi, Edition 2006 ghritavarga /270, p: 368.

21. Acharya Agnivesha, Charaka Samhita, Pt. KashiNathaShashtri, Dr GorakhaNathaShashtri, ChaukhambaBharati Academy, Part 1, Ch. Su.5/12, p: 106.

22. Anil Kumar, SatyanarayanNaik, Ghee: Its Properties, Importance and Health Benefits, lipid universe, January - December 2018, Volume-6

23. R.P. Aneja et al., Technology of Indian milk products, Dairy India publication.: Fat rich dairy products, p: 186.

24. R.P. Aneja et al., Technology of Indian milk products, Dairy India publication. Fat rich dairy products, p: 187.

25. Prof.KrishnachandraChuneker, BhavaprakashaNighantu, Madhuvarga 1-6, ChoukambhaBharatiAcadamy, Varanasi, 2010 edition, p: .773.

26. Acharya Priyavrit Sharma, Dr Guruprasad Sharma, kaiadevaNighantu, ChukambhaOrientalia, Varanasi, Edition 2006 oshadhivarga /175-178, p: 36-37.

27. Adebolu TT. Effect of natural honey on local isolates of diarrhoea causing bacteria in Southwestern Nigeria. African Journal Biotechnology. 2005;4: p: 1172-4.

28. Ashrafi $\mathrm{S}$ et al, Use of Honey in Treatment of Aphthous Ulcers: 2005. P: 9-12.

29. Perez RA et al, Amino acid composition and antioxidant capacity of Spanish honeys. J Agrican Food Chemistry, 2007;55: 360-5.

30. Samarghandian S, Farkhondeh T, Samini F., Honey and Health: A Review of Recent Clinical Research, Pharmacognosy 2017 Apr-Jun;9(2): p: 121-127.

31. SanzML et al. In vitro investigation into the potential prebiotic activity of honey oligosaccharides. Journal Agric Food Chem. 2005;53: p: 2914-21.

32. Schley PD, The immune-enhancing effects of dietary fibres and prebiotics. Journal of Nutrition. 2002;87p: 221-30.

33. Ghosh S, Bioactive natural compounds for the treatment of gastrointestinal disorders. Clinical Science (Lond) 2003;104: p: 547-56.

34. Khalil MI et al. The potential role of honey and its polyphenols in preventing heart diseases: A review. African Journal Tradition Complementary Alternative Medicine. 2010;7: p: 315-21.

35. Schley PD eta 1, The immune-enhancing effects of dietary fibres and prebiotics. journal Nutrition. 2002; 87 p: $221-30$.
36. National honey board (303), Carbohydrate and the Sweetness of Honey, 1 July 2011 at the Wayback Machine.

37. Arcot et al, A Preliminary Assessment of the Glycemic Index of Honey. A report for the Rural Industries Research and Development Corporation. Publication No 05/027.

38. Hunt CL et al, Honey and Its Uses in the Home. US Department of Agriculture, Farmers' Bulletin, No. 653. April 2015.

39. Bogdanov et al, Honey for Nutrition and Health: A Review. J. Am. Coll. Nutr. 2013, p: 677-689.

40. AldinaKesic et al (September 30th, 2015). Phytochemical Profile of Honey, IntechOpen, Available from: https://www.intechopen.com/chapters/48614

41. C.P. Khare, Indian medicinal plants: an illustrated dictionary, Springer Science, NewYork, 2007.

42. F. Xu et al, Determination of cell wall ferulic and pcoumaric acids in sugarcane bagasse, Anal ChimActa 552 (2005) p: 207-217.

43. Acharya Agnivesha, Charaka Samhita, Pt. KashiNathaShashtri, Dr GorakhaNathaShashtri, ChaukhambaBharati Academy, Part 1, Ch. Su.27/241 p: 553.

44. Acharya Shushruta, ShushrutaSamhita, KavirajaAmbika Dutta Shashtri, "Ayurveda TattvaSandipika" Hindi Commentary, ChaukhambaSanskritaSamsthana, Varanasi, 2012, Su. Su.45/162 p: 235.

45. Amandeep Singh et al., Phytochemical profile of sugarcane and its potential health aspects, Pharmacognosy 2015 Jan-Jun, vol.9(17)

46. P.K. Pattnayak et al, Energetic and economics of traditional gur preparation: a case study in Ganjam District of Orissa, India, Biomass Bioenergy 26 (2004) p: 7988.

47. Sen et al. World Journal of Pharmaceutical and Life Sciences 2018, vol:4, issue:4, p: 73-75)

\section{Source of Support: Nil \\ Conflict of Interest: None Declared}

How to cite this URL: Sneha M S \& Rekha. R: Critical Review On Panchamritha - The Magical Combination Which Modifies Life. International Ayurvedic Medical Journal \{online\} 2021 \{cited November 2021\} Available from: http://www.iamj.in/posts/images/upload/3227_3234.pdf 